\title{
Screening and characterization of extracellular polysaccharides produced by Leuconostoc kimchii isolated from traditional fermented pulque beverage
}

\author{
Ingrid Torres-Rodríguez ${ }^{1}$, María Elena Rodríguez-Alegría', Alfonso Miranda-Molina', Martha Giles-Gómez²,
} Rodrigo Conca Morales ${ }^{2}$, Agustín López-Munguía', Francisco Bolívar ${ }^{1}$ and Adelfo Escalante ${ }^{1 *}$

\begin{abstract}
We report the screening and characterization of EPS produced by LAB identified as Leuconostoc kimchii isolated from pulque, a traditional Mexican fermented, non-distilled alcoholic beverage produced by the fermentation of the sap extracted from several (Agave) maguey species. EPS-producing LAB constitutes an abundant bacterial group relative to total $L A B$ present in sap and during fermentation, however, only two EPS-producing colony phenotypes (EPSA and EPSB, respectively) were detected and isolated concluding that despite the high number of polymer-producing LAB their phenotypic diversity is low. Scanning electron microcopy analysis during EPS-producing conditions revealed that both types of EPS form a uniform porous structure surrounding the bacterial cells. The structural characterization of the soluble and cell-associated EPS fractions of each polymer by enzymatic and acid hydrolysis, as by 1D- and 2D-NMR, showed that polymers produced by the soluble and cell-associated fractions of EPSA strain are dextrans consisting of a linear backbone of linked $a-(1 \rightarrow 6) \mathrm{Gl} c p$ in the main chain with $a-(1 \rightarrow 2)$ and $a-(1 \rightarrow 3)$-linked branches. The polymer produced by the soluble fraction of EPSB strain was identified as a class 1 dextran with a linear backbone containing consecutive $a-(1 \rightarrow 6)$-linked D-glucopyranosyl units with few $a-(1 \rightarrow 3)$-linked branches, whereas the cell-associated EPS is a polymer mixture consisting of a levan composed of linear chains of $(2 \rightarrow 6)$-linked $\beta$-D-fructofuranosyl residues with $\beta-(2 \rightarrow 6)$ connections, and a class 1 dextran. According to our knowledge this is the first report of dextrans and a levan including their structural characterization produced by L. kimchii isolated from a traditional fermented source.
\end{abstract}

Keywords: Pulque; Lactic acid bacteria; Leuconostoc kimchii; Exopolysaccharides; Dextran; Levan

\section{Background}

The analysis of the microbial diversity in traditional fermented beverages, cereal doughs and vegetables has revealed the presence of a remarkable diversity of $\mathrm{LAB}$ involved in the development of the characteristic sensorial properties of fermented foods (Giraffa 2004). A wide diversity of EPS and genes encoding biosynthetic enzymes from naturally occurring $\mathrm{LAB}$ in traditional fermented foods and beverages have been extensively studied for

\footnotetext{
* Correspondence: adelfo@ibt.unam.mx

'Departamento de Ingeniería Celular y Biocatálisis, Instituto de Biotecnología, Universidad Nacional Autónoma de México (UNAM), Av. Universidad 2001. Col. Chamilpa, Cuernavaca Morelos 62210, México

Full list of author information is available at the end of the article
}

their role in the physicochemical and sensorial characteristics of final fermented products (viscosifying, stabilizing or water-binding agents). This has led to the discovery of a remarkable structural diversity of EPS produced by LAB, particularly of the genus Leuconostoc and Weissella (Chellapandian et al. 1998; Uzochukwu et al. 2001; Olivares-Illana et al. 2002; Uzochukwu et al. 2002; van Hijum et al. 2006; Eom et al. 2007; Van der Meulen et al. 2007; Bauer et al. 2009; Bounaix et al. 2009; Bounaix et al. 2010; Amari et al. 2012; Vasileva et al. 2012). EPS have received additional attention as valuable products because of their potential economic applications that include natural, safe-food additives or natural functional food ingredients for their properties as soluble fiber and 
prebiotics, and the possibility that they can replace or reduce the use of hydrocolloids (Giraffa 2004; Tieking et al. 2005; Vu et al. 2009; Leemhuis et al. 2013).

Pulque is a traditional Mexican, non-distilled alcoholic fermented beverage currently produced and consumed mainly in the Central Mexico Plateau. It is obtained from the fermentation of a fresh sap, known as aguamiel, which is extracted from several maguey (Agave) species, such as Agave atrovensis and A. americana. The production of this traditional beverage requires for the freshly collected aguamiel to be deposited in large open containers where previously fermented pulque acts as seed for a new batch. Fermentation time varies from a few hours, overnight, or even for several days. Fermented pulque is gradually retired from the container but always leaving a residual volume of the fermented beverage to start a new fermentation. The viscosity resultant from EPS synthesis and the alcohol content of the beverage are the main parameters used to determine the extent of fermentation as they define its distinctive sensorial properties (Escalante et al. 2008; Escalante et al. 2012).

The LAB L. mesenteroides has been traditionally considered one of the most important microorganisms during pulque fermentation as a result of its ability to synthesize EPS, primarily dextrans produced by a glucosyltransferase from sucrose present in aguamiel and pulque (SanchezMarroquin and Hope 1953; Chellapandian et al. 1998; Escalante et al. 2012). Although EPS production by Leuconostoc species isolated from pulque was first reported in 1953, no detailed information was available concerning the properties or structure of these polymers (SanchezMarroquin and Hope 1953). Nevertheless, the structure of an EPS produced by L. mesenteroides strain IBT-PQ isolated from pulque, revealed the presence of a soluble linear dextran with glucose molecules linked primarily by $\alpha-(1 \rightarrow 6)$ bonds with branching from $\alpha-(1 \rightarrow 3)$ bonds, in a 4:1 ratio, and was produced by a cell-associated dextransucrase displaying a similar biochemical behavior to that reported for this enzyme obtained from the industrial strain L. mesenteroides NRRL B512F (Chellapandian et al. 1998).

We have previously reported a great LAB diversity in aguamiel and pulque samples from different geographical origins, that is composed mainly of Lactobacillus and Leuconostoc species (Escalante et al. 2004). Among them $L$. citreum and L. kimchii were reported for the first time to be the most abundant LAB present in aguamiel and during the early stages of pulque fermentation (Escalante et al. 2008). This remarkable abundance of $L$. citreum and L. kimchii in aguamiel and pulque, suggests the presence of a possible diversity of EPS produced by these $\mathrm{LAB}$ during fermentation contributing to the final sensorial properties of the beverage. The aim of the present work was to screen and characterize the EPS diversity associated to the LAB L. kimchii isolated during traditional pulque fermentation. Screening of LAB was based in their ability to produce EPS from sucrose; this method resulted in the identification of two unique EPSproducing colony types. Structural characterization of these polymers including SEM during EPS production conditions, enzymatic and acid hydrolysis, as 1D- and 2D- ${ }^{1} \mathrm{H}$ - and ${ }^{13} \mathrm{C}-\mathrm{NMR}$ allowed the detection of dextran and levan polymers produced by this LAB.

\section{Results and discussion}

\section{Isolation and identification of EPS-producing LAB}

The total EPS-producing $\mathrm{LAB} \mathrm{CFU} / \mathrm{mL}$ detected by growth on APTS plates was $50 \%$ in previously fermented pulque, $47 \%$ in aguamiel, $50.8 \%$ at T0, $70.4 \%$ at T3, and $50 \%$ at the end of the fermentation (T6), compared to the total $\mathrm{LAB} \mathrm{CFU} / \mathrm{mL}$ grown on APT plates. These results indicated a great abundance of EPS-producing LAB in pulque, aguamiel, and during the fermentation process. The visual analysis of purified EPS-producing colonies for unique morphology grown on APTS, allowed the identification of only two EPS colony phenotypes, leading to the conclusion that despite the high number of polymerproducing LAB, phenotypic diversity is low. The fastest growing colony of each EPS type was selected and designated as EPSA (compact colony morphology) and EPSB (creamy colony morphology) (Figure 1).

Analysis of the $16 \mathrm{~S}$ rDNA sequence of strains EPSA and EPSB in the non-redundant database of the NCBI archive database showed that the closest matching sequences found, corresponded to L. kimchii strain IMSNU 11154 (an isolated LAB from Korean kimchi), L. palmae strain TMW 2.694, and diverse L. citreum 16S rDNA sequences in both cases. To precise identity of EPS isolates, a phylogenetic analysis was performed using several Leuconostoc $16 \mathrm{~S}$ rDNA reference sequences retrieved from the GenBank database, such as L. citreum, L. kimchii, L. mesenteroides, and $L$. palmae including type strains. The resulting neighbor-joining tree clearly demonstrated that the $16 \mathrm{~S}$ rDNA sequences of the EPSA and EPSB isolates were placed in a cluster in which only $L$. kimchii sequences were included. However, the $16 \mathrm{~S}$ rDNA sequence from L. palmae strain: TMW 2.694, isolated from palm wine (Ehrmann et al. 2009), was placed in the closest single terminal node separated from the well-defined clusters of the $16 \mathrm{~S}$ rDNA sequences from $L$. kimchii, $L$. citreum, and $L$. mesenteroides (Figure 2). The 16S rDNA sequences corresponding to the EPSA and EPSB L. kimchii strains isolated from pulque were deposited into the GenBank database and accession numbers KC424437 and KC424438 were assigned to strains EPSA and EPSB, respectively. $L$. kimchii strain IMSNU 11154 was originally isolated from traditional Korean kimchi, a traditional fermented vegetable food (Kim et al. 2000). Complete genome sequencing 

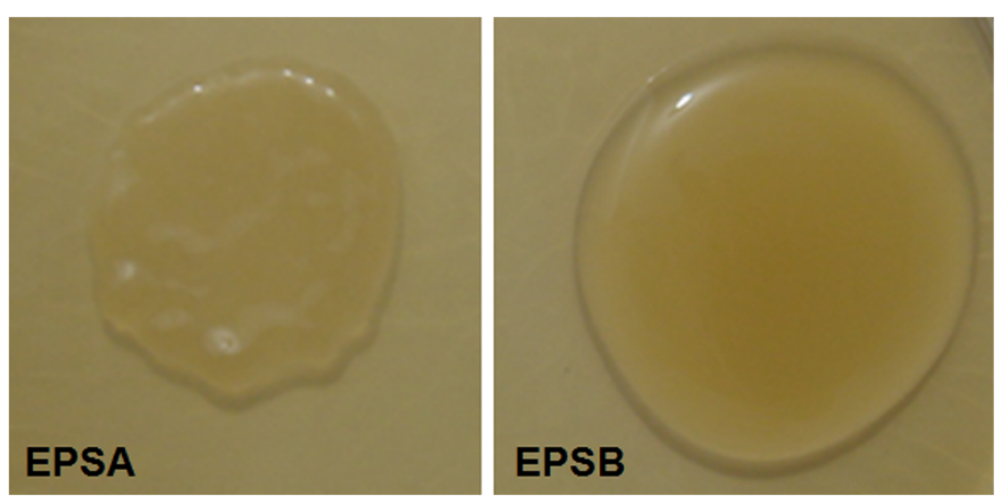

Figure 1 Phenotypic traits of EPS produced by pulque isolated Leuconostoc kimchii strains. Compact left colony or EPSA and creamy right colony or EPSB grown on APT plates supplemented with $20 \%$ sucrose.

of the EPS-producing L. kimchii strain IMSNU 11154 was reported and demonstrated the presence of genes corresponding to GTFs capable to produce dextran from sucrose (Oh et al. 2010).

\section{Scanning electronic microscopy of EPS-producing LAB}

The SEM observation of EPS-producing colonies of EPSA and EPSB growing on APTS plates showed the presence of porous -"cocoon-like" structures associated with the cells (cocci) in both strains. These structures surround the bacterial cells and have different sizes depending on the colony, with larger structures observed for EPSA (Figure 3). Although for both strains a surrounding hollow porous structure is observed, the polymer matrix produced by the EPSB strain appears more compact when compared to the EPSA polymer matrix. No other dextran

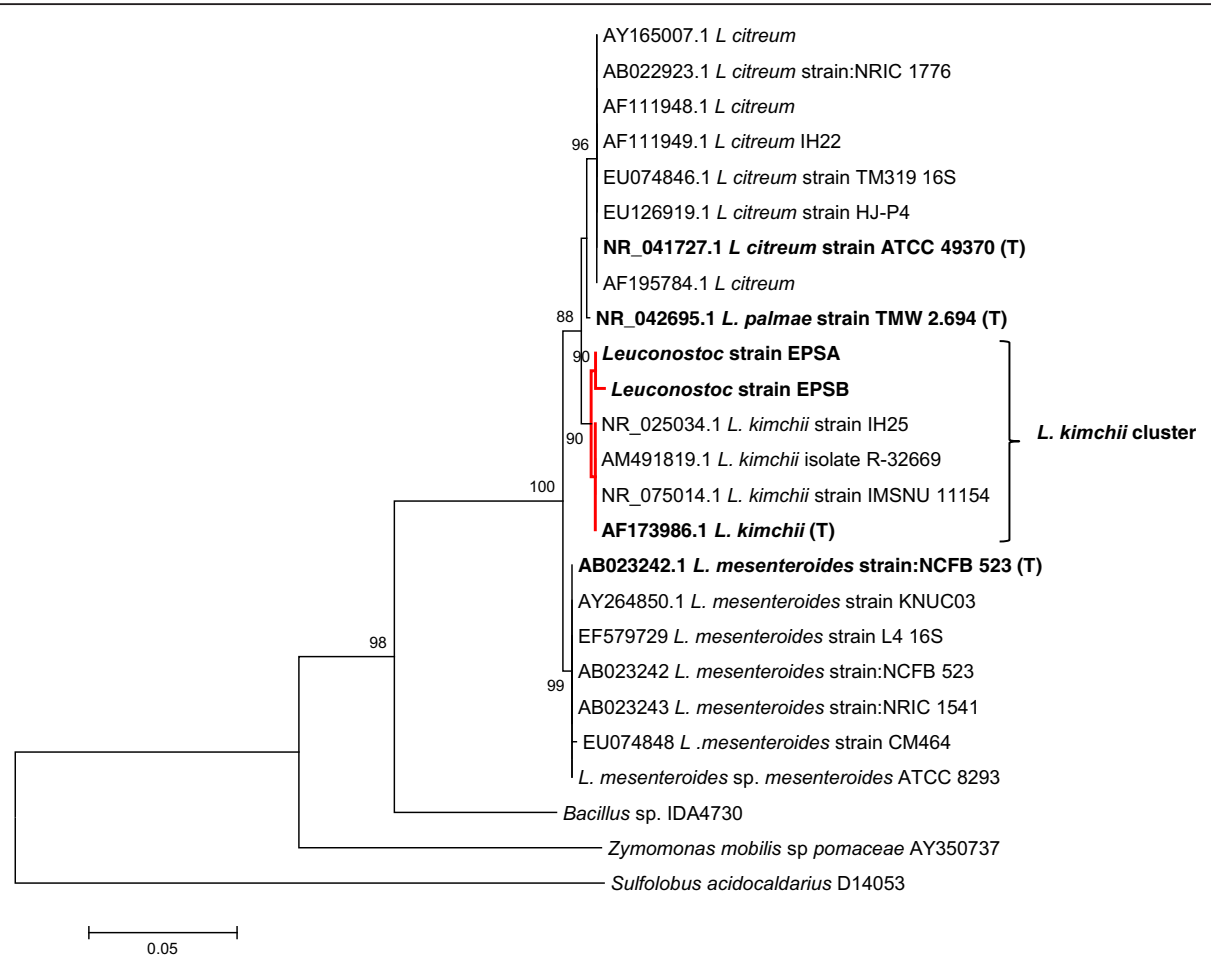

Figure 2 Phylogenetic tree of 16S rDNA sequences of EPSA and EPSB isolates and 16S rDNA reference sequences. Some 165 rDNA sequences of L. citreum, L. palmae, L. kimchii, and L. mesenteroides strains deposited in the GenBank database including type strains of each genus (bold) are included as references. Accession numbers of reference sequences are indicated. The $16 \mathrm{~S}$ rDNA sequences of Sulfolobus acidocaldarius and Zymomonas mobilis are included as outgroups. The percentage of 1000 bootstrap samplings supporting each topological element in the neighbor-joining analysis is indicated. No values are given for groups with bootstrap values less than $80 \%$. L. kimchii cluster including EPSA and EPSB sequences is highlighted. 

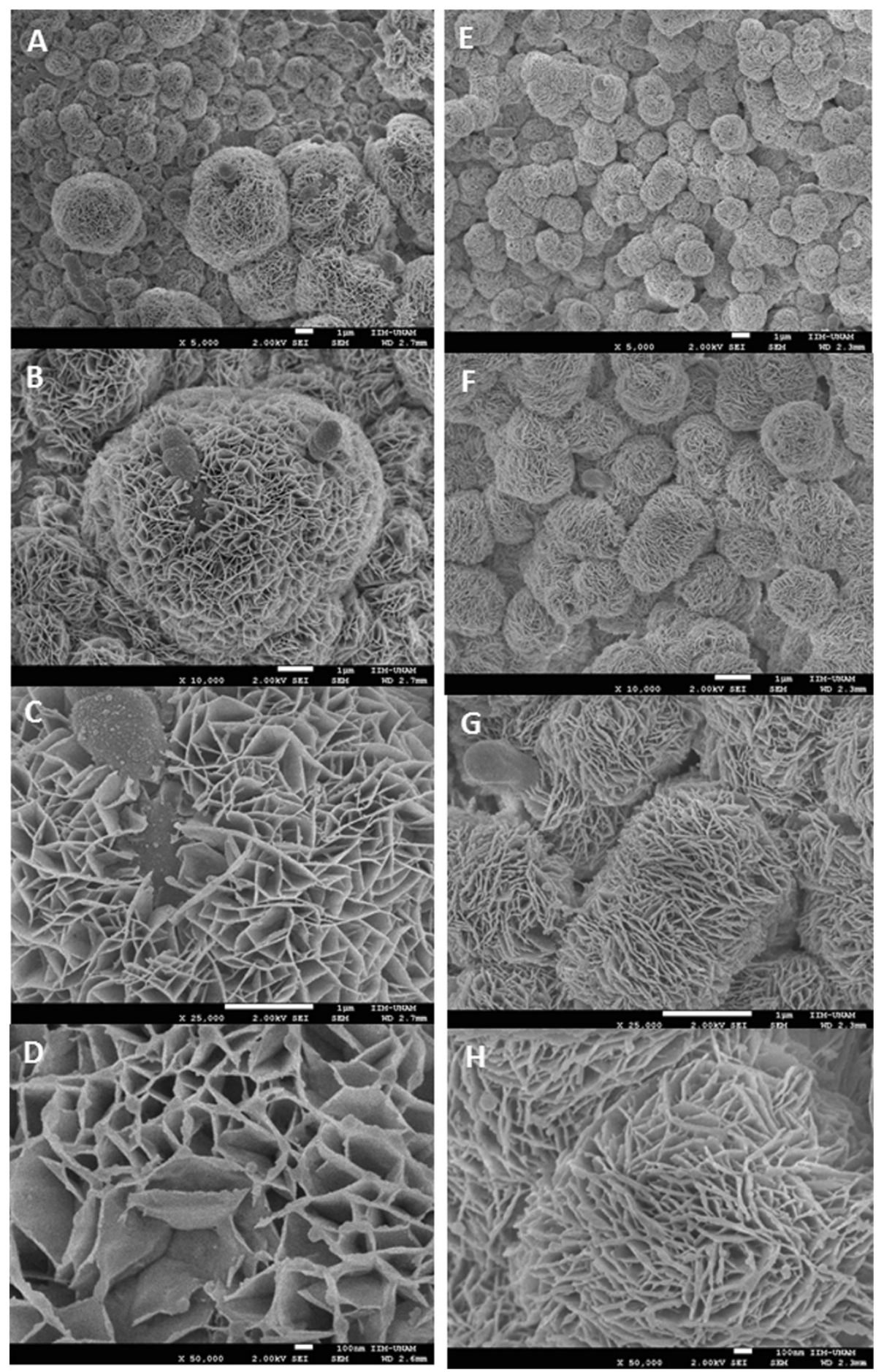

Figure 3 Scanning electron microscopy analysis of EPS-producing Leuconostoc kimchii. Images A-D, correspond to different fields of EPSA producing strain at 5 000X, $10000 X, 25$ 000X, and 50 000X, respectively. Images E-H, correspond to different fields of EPSB producing strain at 5 000X, 10 000X, 25 000X, and 50 000X, respectively.

produced by LAB has been previously analyzed by SEM, although a rather similar porous structure was previously reported for the dried cell-free insoluble dextran produced by L. mesenteroides NRRL B-1149 (Shukla et al. 2011).

\section{Evidence of glycosyltransferase activity}

Total GTF activity was determined either in the cell culture supernatant or associated to the cell fraction of cultures for L. kimchii EPSA and EPSB isolates on APTS 
broth. For the EPSA isolate, a maximum of $3.2 \mathrm{U} / \mathrm{L}$ was observed in the supernatant after $6 \mathrm{~h}$ of fermentation, when the $\mathrm{pH}$ decreased to 4.4. GTF activity was also found to be associated with the cultures's cell fraction showing a maximum activity of $1.8 \mathrm{U} / \mathrm{L}$ after $4 \mathrm{~h}$. When the culture supernatant reached $\mathrm{pH} 5.5$; the insoluble activity was approximately $36 \%$ of the total GTF activity produced by the cells. The total GTF activity was found higher in a similar analysis performed with the EPSB strain. In this case the soluble GTF activity reached $11.21 \mathrm{U} / \mathrm{L}$ after $6 \mathrm{~h}$ of fermentation when the culture supernatant $\mathrm{pH}$ was 4.6 , while the cell-associated GTF activity reached a maximum of $5.57 \mathrm{U} / \mathrm{L}$ after $6 \mathrm{~h}$, representing 33\% of the total GTF activity. These culture conditions were selected to produce soluble and cell-associated polymers for structural characterization. It was also found that the isolated strains EPSA and EPSB showed higher residual total GTF activity in the temperature range of $30^{\circ} \mathrm{C}-40^{\circ} \mathrm{C}$, both in soluble and cell-associated fractions. Regarding the $\mathrm{pH}$, both EPSA and EPSB-soluble fractions showed higher residual total GTF activity at $\mathrm{pH}$ 5.4, while both EPSA and EPSB cell-associated fractions showed higher residual total GTF activity at $\mathrm{pH}$ 6.0.

The GTF activity level associated only to the soluble or cell-associated fractions, or in both fractions ranging 0.8 to $2 \mathrm{U} / \mathrm{mL}$ was previously detected in several Leuconostoc and Weissella isolated strains from fermented sources (Bounaix et al. 2009; Vasileva et al. 2012). Our results showed that the GTF activity detected in the soluble fractions of L. kimchii EPSA and EPSB strains, was higher than the activity found in the cell-associated fractions was but low when compared with previous reports (Bounaix et al. 2010; Bounaix et al. 2009; Vasileva et al. 2012). EPS production by LAB from sucrose was reported that depends on diverse factors such as the cultivation conditions (aerobic, anaerobic and temperature) and media composition (liquid or solid media, rich media such as MRS or APT or mineral media supplemented with phosphate sources, tryptone or yeast extract) (Maina et al. 2008; Minervini et al. 2010). While further investigation is required to determine the fine enzymatic properties of GTF responsibles for soluble and cell-associated EPS production in both EPSA and EPSB L. kimchii isolates, to our knowledge, these results provide evidence that GTF is involved in EPS production by this LAB isolated from a traditional alcoholic fermented beverage for the first time. Previous studies involving both glucosyltransferase and fructosyltransferase characterization have been performed particularly in diverse EPS-producing Leuconostoc, Weissella, and Lactobacillus species isolated from fermented beverages, cereal doughs, and vegetables (Table 1).

\section{EPSA and EPSB characterization} Hydrolysis of soluble and cell-associated EPS fractions Enzymatic hydrolysis assays of the cell-associated and soluble EPSA and EPSB polymer samples showed that polymers produced by the EPSA-soluble and cell-associated GTF were hydrolyzed only by dextranase but not by endolevanase, inulinase or Fructozyme ${ }^{\circ}$. These results indicated the presence of a dextran with $\alpha-(1 \rightarrow 6)$ D-Glc $p$ linkages (Figure 4), similar to dextrans that result from GTF synthesis. Similarly, the polymer produced by the EPSBsoluble fraction was also only hydrolyzed by dextranase, demonstrating the presence of $\alpha-(1 \rightarrow 6)$ D-Glc $p$ linkages as in dextran. Nevertheless, the polymer produced by the EPSB cell-associated fraction was degraded by dextranase, endolevanase and Fructozyme ${ }^{\bullet}$ but not by inulinase, indicating the presence of a polymer mixture composed of a linear dextran and a levan. Furthermore, acid treatment of EPS with $\mathrm{H}_{2} \mathrm{SO}_{4}$ yielded hydrolysis giving the expected monomers.

\section{${ }^{1} \mathrm{H}$ - and ${ }^{13} \mathrm{C}$-NMR analysis of soluble and cell-associated EPSA and EPSB fractions}

As enzymatic hydrolysis demonstrated that soluble and cell-associated fractions of EPSA are the same polymer, only the ${ }^{1} \mathrm{H}$ - and ${ }^{13} \mathrm{C}-\mathrm{NMR}$ spectra of the EPSA-soluble fraction was determined, whereas for the soluble and cellassociated polymers of L. kimchii EPSB strain both spectra were obtained. Resultant NMR spectra were compared with those previously reported for diverse polymers produced by several L. mesenteroides, L. citreum, and Weissella sp. strains (Colson et al. 1974; Seymour et al. 1976; Seymour et al. 1979; Shimamura et al. 1987; Uzochukwu et al. 2001; Uzochukwu et al. 2002; Maina et al. 2008; Bounaix et al. 2009; Vasileva et al. 2012).

Comparison of the NMR results with previously reported spectra for dextrans produced during palm wine fermentation (Uzochukwu et al. 2002) revealed that EPSA is a dextran with a linear backbone of linked $\alpha-(1 \rightarrow 6)$ D-glucopyranosyl units in the main chain confirming enzymatic hydrolysis assay results, but with $\alpha-(1 \rightarrow 2)$ and $\alpha-(1 \rightarrow 3)$ D-Glcp linked branches. The ${ }^{1} \mathrm{H}-\mathrm{NMR}$ spectra showed four anomeric proton signals at $\delta 4.92,5.06,5.13$, and 5.29 labeled A-D, respectively (Figure 5A) corresponding to the $\alpha-(1 \rightarrow 6)$ D-Glcp, the $\alpha-(1 \rightarrow 2)$ branching D-Glcp, the 2,6 di-O-substituted $\alpha$-D-Glc $p$, and the $\alpha-$ $(1 \rightarrow 3)$ D-Glc $p$ units, respectively. The relative intensities of the A-D peaks were $15.30 \%, 12.41 \%, 16.86 \%$, and $55.43 \%$, respectively, resulting proportional to the degree of branching. HSQC of EPSA (Additional file 1) showed their attachment to the anomeric carbons at $\delta 97.64$, $96.15,95.30$, and 99.47 corresponding respectively to ${ }^{1} \mathrm{H}$ anomeric signals at $\delta 4.92,5.06,5.13$, and 5.29 (Figure 5B). These signals characteristically served as the starting point for the analysis of the ${ }^{1} \mathrm{H}-{ }^{1} \mathrm{H}$ COSY and TOCSY experiments for connectivities within the spin system.

The $\mathrm{C}-\mathrm{H}$ correlation spectrum (HSQC) indicated that ${ }^{13} \mathrm{C}$ resonances at $\delta 65.48$ split into two peaks (Additional file 1). The correlation peak showed the ${ }^{1} \mathrm{H}$ resonance at $\delta$ 
Table 1 EPS produced from sucrose by LAB isolated from traditional fermented products

\begin{tabular}{|c|c|c|c|}
\hline EPS type & EPS structure (producing LAB) & Source & Reference \\
\hline Dextran & $\begin{array}{l}\text { Linear backbone linked mainly in a- }(1 \rightarrow 6) \text { D-Glcp with branching in a- }(1 \rightarrow 3) \\
\text { D-Glcp produced by a cell-associated GTF }(L \text {. mesenteroides IBT-PQ strain) }\end{array}$ & $\begin{array}{l}\text { Pulque (fermented } \\
\text { alcoholic beverage) }\end{array}$ & (Chellapandian et al. 1998) \\
\hline \multirow[t]{3}{*}{ Dextran $^{a}$} & $\begin{array}{l}\text { Linear backbone linked mainly in } \mathrm{a}-(1 \rightarrow 6) \mathrm{D}-\mathrm{Gl} c p \text { with branching in } \\
\qquad \mathrm{a}-(1 \rightarrow 2)(L \text {. mesenteroides). }\end{array}$ & Palm wine & (Uzochukwu et al. 2001) \\
\hline & $\begin{array}{l}\text { Linear backbone linked mainly in a- }(1 \rightarrow 6) \mathrm{D}-\mathrm{Gl} c p \text { with branching in } \mathrm{a}-(1 \rightarrow 3) \\
\text { with minor } \mathrm{a}-(1 \rightarrow 4) \text { linked branches }(L \text {. dextranicum). }\end{array}$ & & \\
\hline & $\begin{array}{l}\text { Linear backbone linked mainly in a- }(1 \rightarrow 6) \text { D-Glcp with branching in a- }(1 \rightarrow 3) \\
\text { (Lactobacillus spp. AW strain) }\end{array}$ & & \\
\hline Fructan & $\begin{array}{l}\text { Inuline-like structure with } \beta \text { - }(2 \rightarrow 1) \text { glycosidic linkages produced by a } \\
\text { cell-associated fructosyltransferase }(L \text {. citreum) }\end{array}$ & $\begin{array}{l}\text { Pozol (maize } \\
\text { fermented dough) }\end{array}$ & (Olivares-Illana et al. 2002) \\
\hline \multirow[t]{2}{*}{ Dextran $^{a}$} & $\begin{array}{c}\text { Dextran type I containing a- }(1 \rightarrow 2) \text { D-Glcp and a- }(1 \rightarrow 3) \text { linked branches } \\
\text { (L. citreum VTT E-93497 strain). }\end{array}$ & Malting process & (Maina et al. 2008) \\
\hline & Dextran type I containing few a- $(1 \rightarrow 3)$ linked branches (W. confusa VTT E-90392 strain) & Soured carrot mash & \\
\hline \multirow[t]{3}{*}{ Dextran } & $\begin{array}{l}\text { Dextran type I linked mainly in a- }(1 \rightarrow 6) \text { D-Glcp with few a- }(1 \rightarrow 3) \text { linked branches } \\
\text { produced by soluble GTF (Several } L \text {. mesenteroides and Weissella spp isolates) }\end{array}$ & $\begin{array}{l}\text { Traditional French } \\
\text { wheat sourdough }\end{array}$ & (Bounaix et al. 2009) \\
\hline & $\begin{array}{l}\text { Dextran type I linked mainly in a- }(1 \rightarrow 6) \text { D-Glcp with a- }(1 \rightarrow 2) \text { linked branches } \\
\text { produced by soluble GTF (several } L \text {. mesenteroides and } L \text {. citreum isolates) }\end{array}$ & & \\
\hline & $\begin{array}{c}\text { Dextran type I linked mainly in a- }(1 \rightarrow 6) \text { D-Glcp with high a- }(1 \rightarrow 3) \text { linked branches } \\
\text { produced by soluble GTF (Several L. citreum isolates) }\end{array}$ & & \\
\hline Dextran/levan mixture & $\begin{array}{l}\text { Dextran type I linked mainly in a- }(1 \rightarrow 6) \text { D-Glcp with high a- }(1 \rightarrow 3) \text { linked branches produced } \\
\text { by soluble and cell-associated GTF mixed with a levan (several L. mesenteroides isolates) }\end{array}$ & $\begin{array}{l}\text { Traditional French } \\
\text { wheat sourdough }\end{array}$ & (Bounaix et al. 2009) \\
\hline Dextran & Dextran type I linked mainly in $a-(1 \rightarrow 6)$ D-Glcp with few a- $(1 \rightarrow 2)$ linked branches (W. confusa LBAE C39-2) & $\begin{array}{l}\text { Traditional French } \\
\text { wheat sourdough }\end{array}$ & (Amari et al. 2012) \\
\hline Dextran $^{a}$ & Linear backbone linked mainly in a-(1 $\rightarrow 6)$ D-Glcp (Lactobacillus curvatus 69B2 strain and Leuconostoc lactis 95A strain) & Wheat sourdough & (Palomba et al. 2012) \\
\hline Dextran & $\begin{array}{c}\text { Linear backbone linked mainly in a- }(1 \rightarrow 6) \text { D-Glcp with a- }(1 \rightarrow 3) \text { linked branches produced } \\
\text { by soluble and cell-associated GTF }(L \text {. mesenteroides })\end{array}$ & $\begin{array}{l}\text { Bulgarian fermented } \\
\text { vegetables }\end{array}$ & (Vasileva et al. 2012) \\
\hline Dextran/levan mixture & 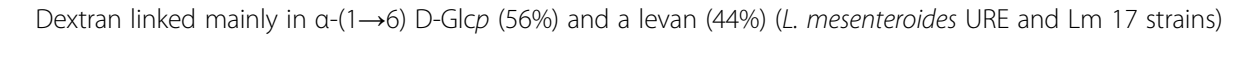 & $\begin{array}{l}\text { Bulgarian fermented } \\
\text { vegetables }\end{array}$ & (Vasileva et al. 2012) \\
\hline Dextran $^{a}$ & Linear backbone linked mainly in $a-(1 \rightarrow 6)$ D-Glcp (L. mesenteroides and $W$. confusa) & $\begin{array}{l}\text { Kimchi (traditional } \\
\text { fermented } \\
\text { vegetable food) }\end{array}$ & (Park et al. 2013) \\
\hline \multirow[t]{2}{*}{ Dextran } & $\begin{array}{c}\text { Linear backbone linked mainly in a- }(1 \rightarrow 6) \text { D-Glcp with a- }(1 \rightarrow 2) \text { and a- }(1 \rightarrow 3) \text { linked branches produced } \\
\text { by a soluble and cell-associated GTF }(L . \text { kimchii EPSA strain) }\end{array}$ & Pulque & This work \\
\hline & Dextran type I containing few a- $(1 \rightarrow 3)$ linked branches produced by a soluble GTF (L. kimchii EPSB strain) & & \\
\hline Levan/dextran mixture & $\begin{array}{l}\text { Polymer mixture composed by linear chains of }(2 \rightarrow 6) \text {-linked } \beta \text {-D-fructofuranosyl residues with connections } \\
\beta-(2 \rightarrow 6)(79 \%) \text {, and a dextran Type I }(21 \%) \text { produced by the cell-associated GTF fraction (L. kimchii EPSB strain) }\end{array}$ & Pulque & This work \\
\hline
\end{tabular}



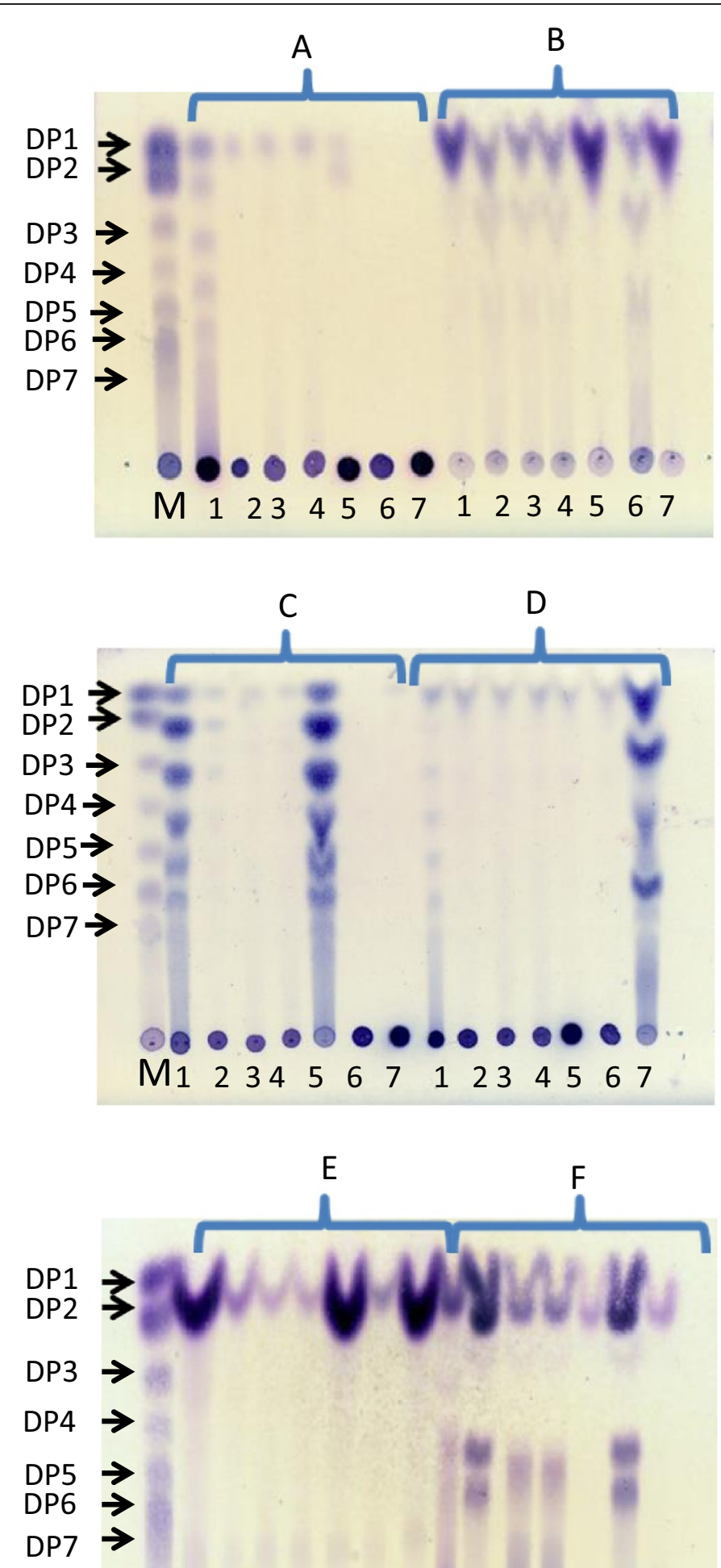

$\mathrm{M} 1223455677_{1} 234567$

Figure 4 (See legend on next page.) 
(See figure on previous page.)

Figure 4 Enzymatic and acid hydrolysis of EPSA and EPSB polymers. 1. EPSB cell-associated fraction; 2. EPSB-soluble fraction; 3. EPSA cell-associated fraction; 4. EPSA-soluble fraction; 5. Levan from B. subtilis; 6. Dextran from L. mesenteroides B-512; 7. Inulin from L. citreum. M. Glucose + fructose + maltodextrins standards; A. Non-treated samples; B. Acid hydrolysis treatment; $\mathbf{C}$. Endolevanase treatment; $\mathbf{D}$. Endoinulinase treatment; $\mathbf{E}$. Fructozyme ${ }^{\circledast}$ treatment; $\mathbf{F}$. Dextranase treatment. DP = Degree of polymerization.

3.70 and $\delta$ 3.93. The other ${ }^{13} \mathrm{C}$ peaks at $\delta 60.32,60.47$, and 60.65 showed their protons as a multiplet at $\delta 3.78$ and $\delta$ 3.66 which corresponded to non-linked C-6. The previous characterization of dextrans from fermented palm wine showed that its backbone contains a bound C- 6 with a chemical shift at $\delta 66.6$ (Uzochukwu et al. 2002), whereas for EPSA polymer it was found at $\delta 65.48$, resulting farthest downfield than a free C-6 at $\delta 61.4(\delta 60.32,60.47$, and 60.65 for EPSA polymer). Finally, the long-range correlation between $\mathrm{H}-3$ ( $\delta 3.81)$ and the anomeric carbon at $\delta 99.47$ of EPSA polymer in the HMBC spectrum allowed to confirm the presence of $\alpha-(1 \rightarrow 3)$-linked branches (Additional file 1).

Furthermore, in the $\delta 68-74$ region of the ${ }^{13} \mathrm{C}-\mathrm{NMR}$ spectrum of EPSA, were found characteristic branching signals for linked $\mathrm{C}-2$ and $\mathrm{C}-3$ at branching points, which split in three peaks found in $\delta 71.83,71.56$, and 71.31; and in the region at $\delta 69.53,69.46$, and 69.31 , respectively (Figure $5 \mathrm{~b}$ ). These data were consistent with previous results of spectra for the series of dextrans B1254, B1355S, and B1099L (Seymour et al. 1976). The split in the free C-6 around $\delta$ 60-61 represents C-6 in different chemical environments with two possible sources of branchterminating residues: $\alpha-(1 \rightarrow 2)$ and $\alpha-(1 \rightarrow 3)$ branching. Free C-6 signals in EPSA polymer were detected at $\delta$ $60.32,60.47$, and 60.65 , respectively and were associated with branching at C-2 and C-3, respectively, indicating that in EPSA polymer the linkage is present both as branch point and intra chain linkages as reported previously for palm wine dextran (Uzochukwu et al. 2002).

NMR spectra results for EPSB polymers corroborated that its soluble fraction is a dextran with a linear backbone containing consecutive $\alpha$ - $(1 \rightarrow 6)$-linked $\mathrm{D}$-glucopyranosyl units with few $\alpha-(1 \rightarrow 3)$-linked branches, structure characteristic of class 1 dextrans (Maina et al. 2008; Amari et al. 2012). The ${ }^{1} \mathrm{H}-\mathrm{NMR}$ spectrum for EPSB-soluble fraction (Figure 6A), revealed anomeric signals characteristic of glucosyl residues linked through $\alpha-(1 \rightarrow 6)(98.5 \%)$ and $\alpha-$ $(1 \rightarrow 3)(1.5 \%)$ linkages appeared at $\delta 4.97$ and $\delta 5.3$, respectively. The other protons appeared from $\delta 3.4$ to 4.1 :

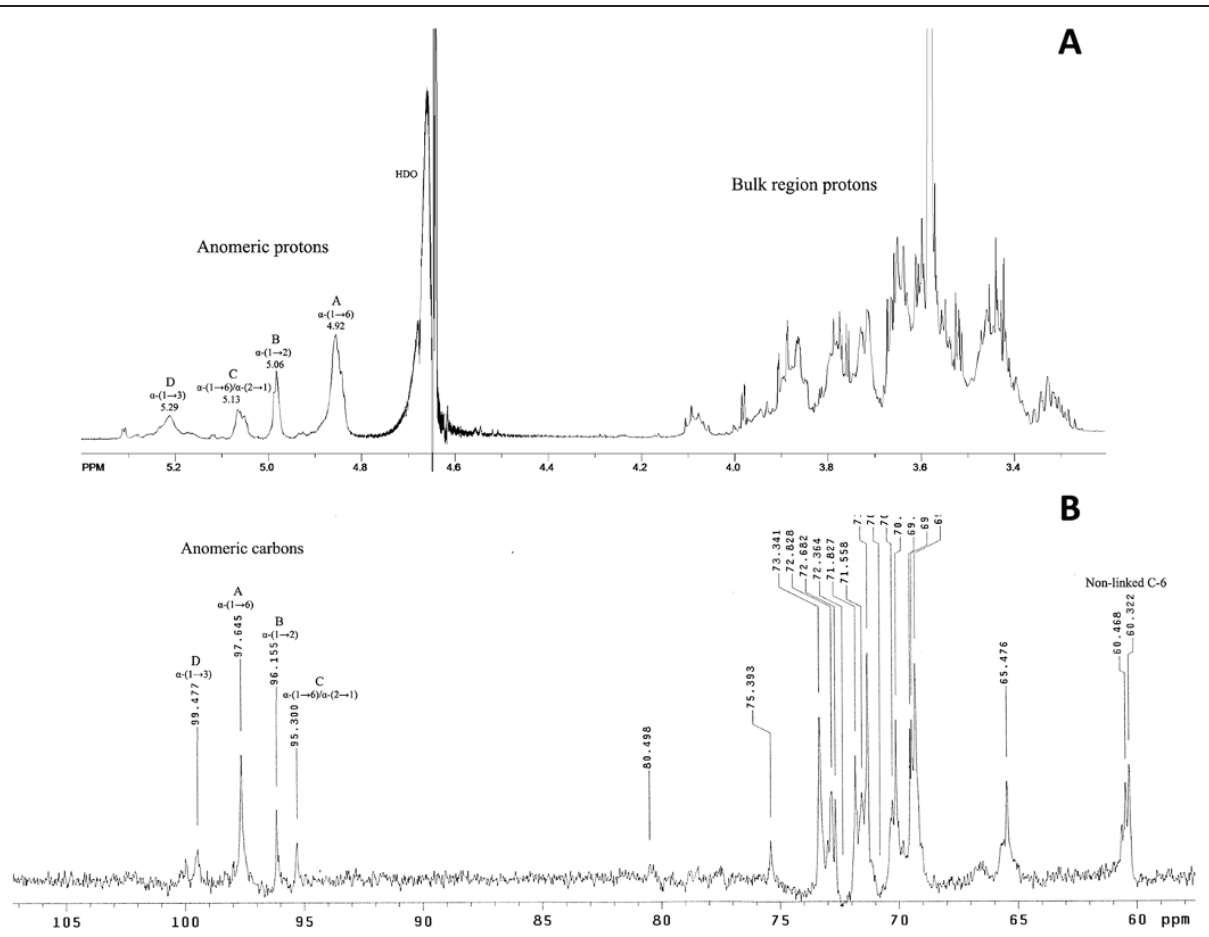

Figure 5 NMR spectra of EPSA soluble fraction. (A) ${ }^{1} \mathrm{H}-\mathrm{NMR}$ spectrum. (B) ${ }^{13} \mathrm{C}-\mathrm{NMR}$ spectrum. Anomeric protons are labeled $\mathrm{A}-\mathrm{D}$ according to the increasing chemical shifts. 


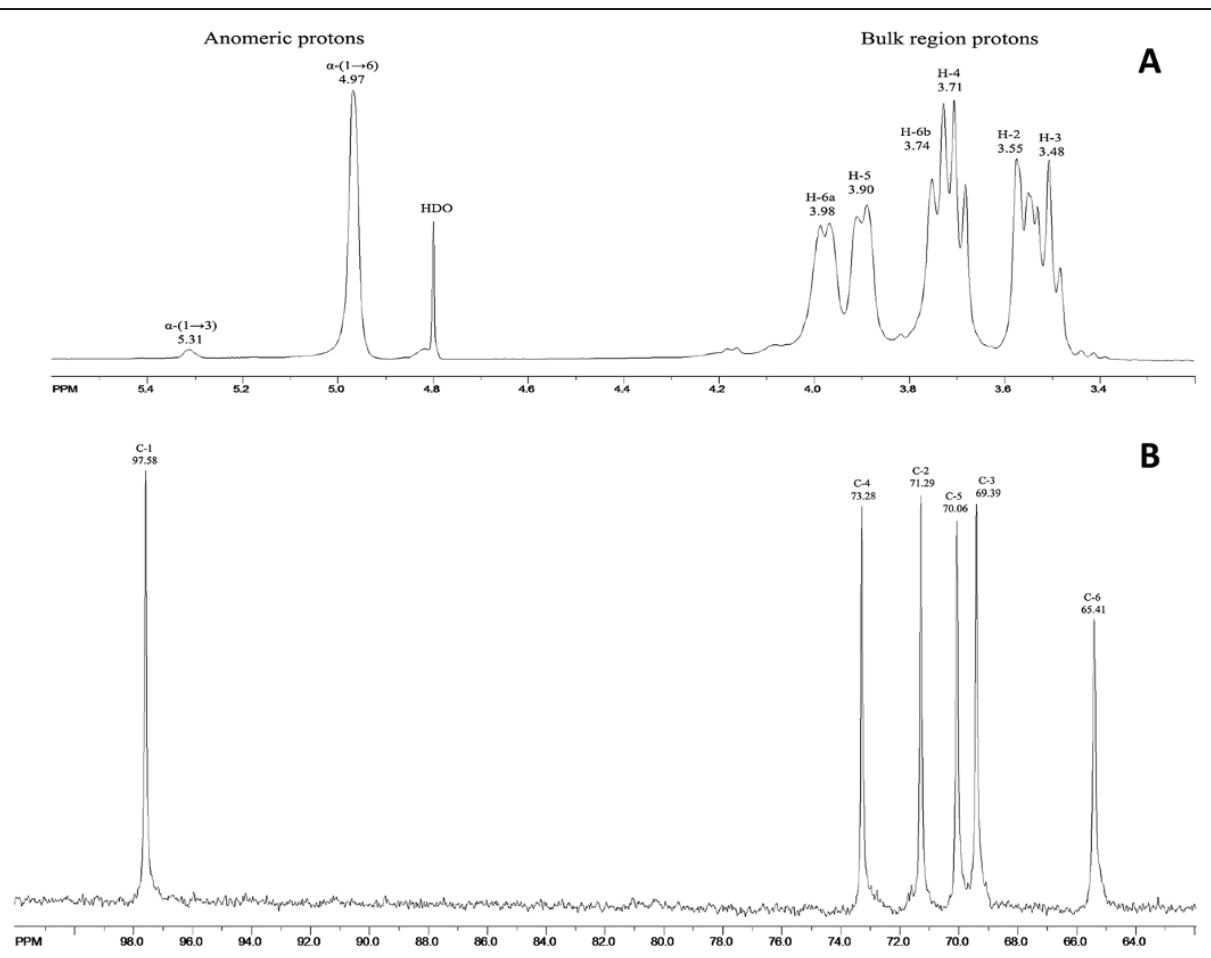

Figure 6 RMN spectra of EPSB-soluble fraction. (A) ${ }^{1} \mathrm{H}-\mathrm{NMR}$ spectrum. (B) ${ }^{13} \mathrm{C}-\mathrm{NMR}$ spectrum.

$\delta=3.55(\mathrm{dd}, 1 \mathrm{H}, J=3.2 \mathrm{~Hz}, J=9.8 \mathrm{~Hz}, \mathrm{H}-2), 3.48(\mathrm{t}, 1 \mathrm{H}$, $J=9.2 \mathrm{~Hz}, J=9.6 \mathrm{~Hz}, \mathrm{H}-3), 3.71(\mathrm{t}, 1 \mathrm{H}, J=9.2 \mathrm{~Hz}, J=$ $9.6 \mathrm{~Hz}, \mathrm{H}-4), 3.90$ (d, $J=8.4,1 \mathrm{H}, \mathrm{H}-5), 3.74(\mathrm{~d}, J=7.48, \mathrm{H}-$ 6a), 3.98 (d, $J=9.76,1 \mathrm{H}, \mathrm{H}-6 \mathrm{~b})$. The ${ }^{13} \mathrm{C}-\mathrm{NMR}$ spectrum (Figure 6B) shows six signals, among them, those appearing at $\delta 97.56$ and $\delta 65.41$, corresponding to $C-1$ and $C-6$, which are involved in $\alpha-(1 \rightarrow 6)$ linkages. The linkage carbon resonance at $\delta 65.41$ showed two correlation peaks ( $\delta 3.74$ and $\delta 3.98$ ) in the HSQC spectrum (Additional file 1). The four remaining signals observed at $\delta 73.28$, 70.06, 69.39, and 71.29 corresponded to C-4, C-5, C-3, and $\mathrm{C}-2$, respectively. Full assignments of the proton and carbon resonances were secured from the TOCSY, COSY, NOESY, and HMBC data.

These results are consistent with previous reported ${ }^{1} \mathrm{H}$ - and ${ }^{13} \mathrm{C}$-NMR data for the dextran produced by $W$. confusa C39-2 strain with $97.6 \% \alpha-(1 \rightarrow 6)$ and $2.4 \% \alpha-$ $(1 \rightarrow 3)$ linkages, respectively (Bounaix et al. 2009). The structure of the soluble EPSB dextran also resembled that of dextrans produced by W. confusa VTT E-90392 (ODSM 20194) (Maina et al. 2008) and W. cibaria CMGDEX3 (Ahmed et al. 2012).

In other hand, the ${ }^{1} \mathrm{H}$ - and ${ }^{13} \mathrm{C}$-NMR chemical shifts observed suggest that the polymer from the cell-associated fraction of isolated strain EPSB is a mixture that consist of a levan $(79 \%)$ composed of linear chains of $(2 \rightarrow 6)$-linked $\beta$-D-fructofuranosyl residues with $\beta$ - $(2 \rightarrow 6)$ linkages, and a polymer of class 1 dextran (21\%). The assignments of methylene and methine carbons were determined by a DEPT analysis (Additional file 1). The ${ }^{13} \mathrm{C}$-NMR spectrum gave three upfield resonances which were methylene $\left(\delta_{\mathrm{C}} 59.83,63.32,65.46\right)$ while the remaining resonances were methines and one quaternary carbon $\left(\delta_{C} 104.13\right)$.

The ${ }^{1} \mathrm{H}$-NMR spectrum showed intense signals associated to the fructose moieties in the levan fraction (Figure 7A), which were detected at $\delta 3.77(\mathrm{~d}, J=12.6 \mathrm{~Hz}, \mathrm{H}-6 \mathrm{a}), 3.44$ (d, $J=11.2 \mathrm{~Hz}, \mathrm{H}-6 \mathrm{~b}), \delta 3.55$ (d, $J=11.9 \mathrm{~Hz}, \mathrm{H}-1 \mathrm{a}), \delta 3.64$ (d, $J=11.9 \mathrm{~Hz}, \mathrm{H}-1 \mathrm{~b}), \delta 3.82$ (ddd, $J=2.8 \mathrm{~Hz}, J=7.7 \mathrm{~Hz}$, $J=7.7 \mathrm{~Hz}, \mathrm{H}-5), \delta 3.96(\mathrm{t}, J=7.7 \mathrm{~Hz}, J=8.4 \mathrm{~Hz}, \mathrm{H}-4)$, $\delta 4.06(\mathrm{~d}, J=8.4 \mathrm{~Hz}, \mathrm{H}-3)$. The COSY spectrum was used to detect cross peaks between $\mathrm{H}-3 / \mathrm{H}-4, \mathrm{H}-4 / \mathrm{H}-5$, and $\mathrm{H}-5 / \mathrm{H}-6$. The HMBC spectrum (Additional file 1) showed the presence of cross peaks between $\mathrm{H} 3 / \mathrm{C} 4, \mathrm{H} 4 /$ $\mathrm{C} 6, \mathrm{H} 4 / \mathrm{C} 3, \mathrm{H} 1 / \mathrm{C} 3$, and $\mathrm{H} 1 / \mathrm{C} 2$ as it was reported previously (Dahech et al. 2013). This result allowed to confirm the presence of $\beta-(2 \rightarrow 6)$ linkage between two fructofuranosyl moieties, but the $\beta-(2 \rightarrow 6)$ linkage was confirmed only by the presence of a downfield shifted signal at $\delta$ 63.32 (C-6) in the ${ }^{13} \mathrm{C}-\mathrm{NMR}$ spectrum as reported previously (Tomašić et al. 1978). It has been shown that normally glycosylation induces a downfield shift of $\delta$ 4-10 (Newbrun and Baker 1968). In the ${ }^{13} \mathrm{C}-\mathrm{NMR}$ spectrum (Figure 7B) of the EPSB cell-associated polymer were detected six main resonance shifts at $\delta 59.83(\mathrm{C}-1), \delta 63.32$ 

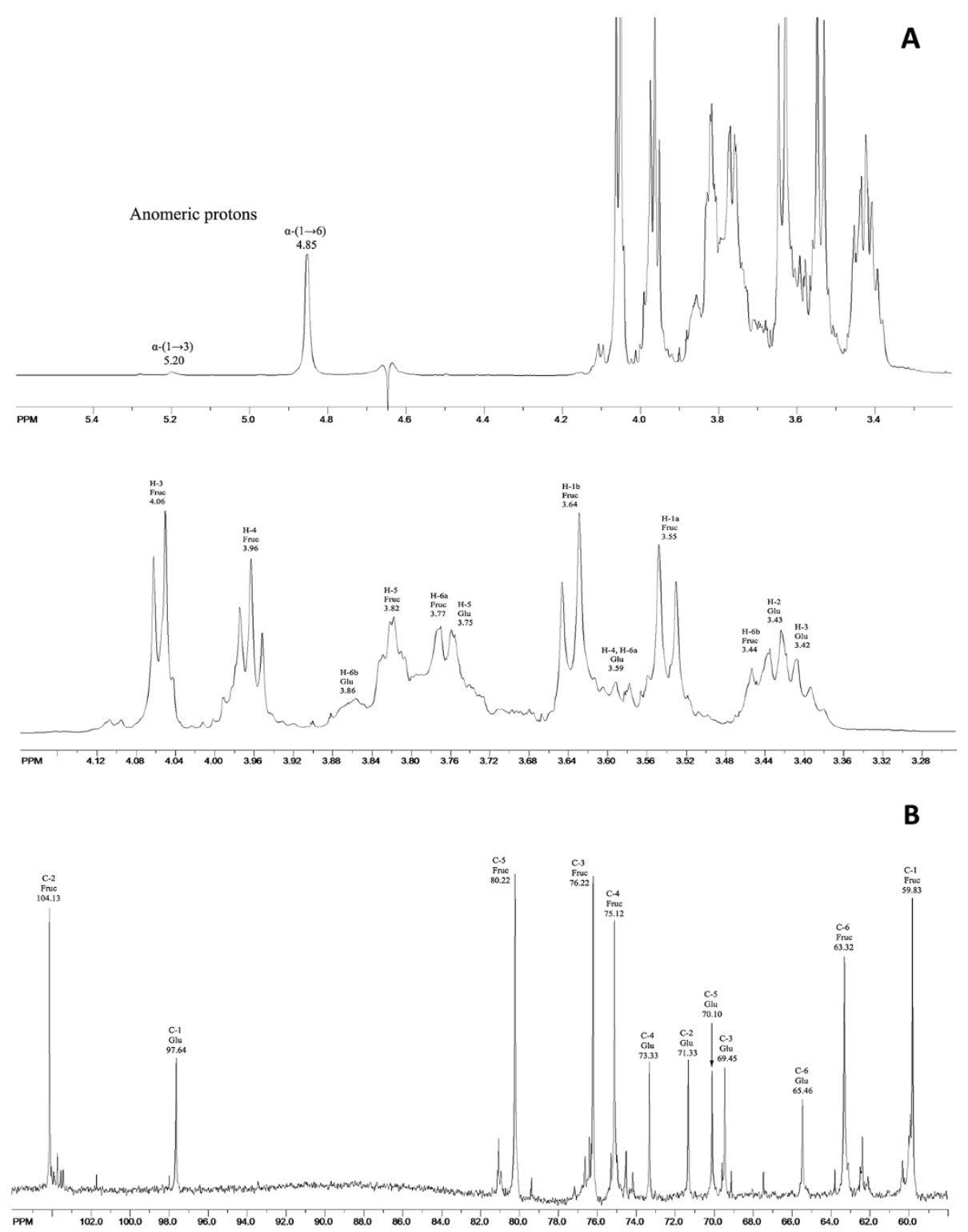

Figure 7 RMN spectra of EPSB-soluble and cell-associated fractions. (A) Full ${ }^{1} \mathrm{H}$ NMR spectrum (upper graph) and region between 4.2 and $3.1 \mathrm{~nm}$ (bottom graph). (B) ${ }^{13} \mathrm{C}-\mathrm{NMR}$ spectrum.

(C-6), $\delta 75.12(\mathrm{C}-4), \delta 76.22(\mathrm{C}-3), \delta 80.22(\mathrm{C}-5)$, and $\delta$ $104.13(\mathrm{C}-2)$ relating to a quaternary anomeric carbon, corresponding to levan. These results are also similar to those observed previously in levan produced by $L$. mesenteroides B-512 F (Morales-Arrieta et al. 2006) and Streptococcus mutans (Shimamura et al. 1987).

According to 1D- and 2D-NMR analysis, the second polymer in the mixture corresponded to dextran. The chemical shifts for the 6 carbons of the dextran were linked to those of the seven hydrogens as determining by using HSQC (Additional file 1). The characteristically downfield anomeric carbon $(\delta 97.64)$ and anomeric hydrogen $(\mathrm{d}, \delta 4.85, J=1.4 \mathrm{~Hz}$ ) was considered as the starting point for the analysis of the ${ }^{1} \mathrm{H}_{-}{ }^{1} \mathrm{H}$ COSY (Additional file 1) for connectivity within the spin system. The two diasterotopic H-6 hydrogens at $\delta 3.86(\mathrm{~m})$ and at $\delta$ $3.59(\mathrm{~m})$ in the ${ }^{1} \mathrm{H}$ spectrum were also useful markers and attached to the carbon at $\delta 65.46$ in the ${ }^{13} \mathrm{C}$ spectrum. The other protons appeared in the spectrum at: $\delta=3.43(\mathrm{H}-2)$, 3.42 (H-3), 3.59 (H-4 and H-6a), 3.75 (H-5), 3.86 (H-6b). In the ${ }^{13} \mathrm{C}$-NMR spectrum, the peaks corresponding to individual carbons were identified at $\delta \mathrm{C}-4$ (73.33), C-2 (71.33), C-5 (70.10), C-3 (69.45), and C-6 (65.46), respectively (Figure 7B).

Polymers synthesized by GTF from sucrose by diverse LAB isolated from different traditional fermented sources 
include linear and branched dextrans, dextran and levan mixtures, and also inulin like polymers, indicating a high natural diversity of these EPS, particularly interesting considering the wide geographical distribution of these fermented products: palm wine from Africa, cereal sourdoughs and fermented vegetables from Europe, traditional kimchi from Korea, and maize sourdough and a fermented pulque beverage from Mexico (Table 1). The production of a dextran and levan polymers mixture was previously detected in the cell-associated fraction of cultures on MRS-sucrose of L. mesenteroides G15 strain isolated from a French cereal sourdough as revealed by ${ }^{13} \mathrm{C}-\mathrm{NMR}$ spectroscopy (Bounaix et al. 2009). Interestingly, detection of genes coding for glucosyltransferase and enzymes demonstrated their respective presence in isolated $L$. mesenteroides strains from Bulgarian fermented vegetables, but activity of putative fructosyltransferase was detected only in the presence of raffinose instead sucrose (Vasileva et al. 2012). Additionally, the production of an inulin-like polymer with $\beta-(2 \rightarrow 1)$ glycosidic linkages, was demonstrated by ${ }^{13} \mathrm{C}$-NMR in a cell-associated fructosyltrasferase in cultures containing $20 \mathrm{~g} / \mathrm{L}$ sucrose of $\mathrm{L}$. citreum strain CW isolated from pozol, a Mexican fermented maize sourdough (Olivares-Illana et al. 2002) (Table 1).

Several polymers described in Table 1 have relevant potential applications, as it has been proposed that branched dextrans possess prebiotic properties, demonstrating that these polymers and their oligodextrans may be substrates for butyric acid production by intestinal microbiota. Additionally, highly linear dextrans are considered highly soluble and were proposed to confer viscosity properties associated to their molecular weight (Maina et al. 2008). Furthermore, levans were shown to exhibit prebiotic effects, attracting attention for its antitumor properties, cholesterol-lowering properties and application such ecofriendly adhesive and as a promising bio-thickener in food industry (Patel et al. 2011). Pulque beverage is consumed directly from the fermentation vessel without further antimicrobial treatment such as pasteurization or filtration, as a consequence, living microorganisms are consumed. Additionally, pulque has been traditionally considered has a healthy beverage due to its nutrient content and used as a natural medicine to control several diseases (Escalante et al. 2012). Even though proposed healthy effects have been limited to traditional pharmacopoeia, further evidence on the possible probiotic effect of LAB involved in the fermentation process as the possible prebiotic activity of dextran or dextran and levan mixture produced by LAB such L. kimchii EPSA and EPSB strains requires further investigation.

\section{Conclusions}

EPSA and EPSB producing strains of L. kimchii isolated from traditional Mexican pulque and their polymers described in this contribution are to our knowledge the first study reporting the production and characterization of EPS produced by this LAB isolated from traditional fermented sources. L. kimchii was previously identified as the main $\mathrm{LAB}$ present in agave sap aguamiel and during the first hours of pulque fermentation. Although further studies are required to provide additional information concerning the enzymatic properties of the GTF responsibles for the synthesis of dextrans and levan by L. kimchii EPSA and EPSB strains, results presented in this contribution are highly relevant for pulque microbiology. In effect, while $L$. mesenteroides has traditionally been considered the main bacteria responsible for polymer production during pulque fermentation, this study provides new evidence regarding the diversity of EPS produced by LAB involved in the production of this traditional Mexican beverage.

\section{Methods}

\section{Aguamiel and pulque sampling}

Fresh aguamiel and fermented pulque were collected from the town of Hiutzilac, State of Morelos, Mexico (Central Mexico Plateau) and transported to the laboratory, where controlled fermentations were performed by the addition of fresh sap to previously fermented pulque as described before (Escalante et al. 2008). Samples of aguamiel, after inoculation (mixing of sap with previously fermented pulque) (sample T0) and after 3 and $6 \mathrm{~h}$ of fermentation, were serially diluted in $0.1 \%$ tryptone water (DIFCO), and aliquots of $0.1 \mathrm{~mL}$ were plated on APT-agar (DIFCO) and APT-agar supplemented with $20 \%(\mathrm{w} / \mathrm{v})$ sucrose (APTS). Plates were then incubated at $30^{\circ} \mathrm{C}$ for $24 \mathrm{~h}$ to determine the total count of $\mathrm{LAB}$ and EPS-producing LAB, respectively.

\section{EPS-producing $L A B$ isolation and identification}

An average of 100 colonies of EPS-producing LAB from representative plates of aguamiel and each pulque sample were isolated, Gram stained, observed with a light microscope to verify colony purity, and tested for catalase activity. The purified isolated colonies were grown on APTS plates (4 colonies per plate), where the colony morphology and size were visually screened. Fast growing colonies were selected and visually screened for unique EPS-producing phenotypes resulting in the identification of two distinct EPS-producing colonies designated as EPSA and EPSB. Finally, selected isolates were conserved in $50 \%$ glycerol at $-70^{\circ} \mathrm{C}$ and identified by $16 \mathrm{~S}$ rDNA sequencing as described previously (Escalante et al. 2004; Escalante et al. 2008) by using fd1 + rd1 primer set resulting in the amplification of the entire $16 \mathrm{~S}$ rRNA gene (Weisburg et al. 1991). Comparison was performed against the non-redundant nucleotide database using the online nucleotide BLAST application in the NCBI homepage. To corroborate their molecular identity, 
a phylogenetic tree was constructed using MEGA 6 software (Tamura et al. 2013) including reference and type $16 \mathrm{~S}$ rDNA sequences retrieved from the NCBI database.

\section{Scanning electron microscopy analysis of EPS-producing LAB}

EPS-producing LAB were grown on APTS plates until a viscous morphology was observed. Collodion-coated electron microscope grids were placed on growing colonies, and maintained for four additional days at room temperature to promote LAB adhesion to the grid. The grids were then lifted from the APTS plates and placed on a porcelain spot dish for further processing. Fixation was performed by $1 \mathrm{~h}$ of exposure to $1 \%$ paraformaldehyde and $2.5 \%$ glutaraldehyde in $\mathrm{pH}$ 7.4, $0.1 \mathrm{M}$ phosphate buffer, followed by washing with the same buffer, post-fixing with $1 \%$ osmium tetroxide in buffer for $30 \mathrm{~min}$ and dehydration with graded alcohols. Throughout the procedure, special care was taken when changing solutions to avoid EPS dispersion and damage to the grid surface. The samples were then dried under critical $\mathrm{CO}_{2}$ (Sandri-780; Tousimis), gold coated (JFC-110 ion sputter; JEOL), and observed with a JEOL JSM-7600 F Field Emission SEM.

\section{Growth kinetics of EPS-producing strains}

Flask cultures were performed in $50 \mathrm{~mL}$ of APT broth at $30^{\circ} \mathrm{C}$ and $150 \mathrm{rpm}$ to define optimum growth conditions for selected LAB isolates and to achieve adequate enzyme activities and EPS production. The $\mathrm{OD}_{600 \mathrm{~nm}}$ was determined and adjusted to 0.2 before inoculation in a $2.8 \mathrm{~L}$ flask with $560 \mathrm{~mL}$ of APT broth and incubation for $6-8 \mathrm{~h}$ at $30^{\circ} \mathrm{C}$ and $150 \mathrm{rpm}$. Microbial growth was followed by the $\mathrm{OD}_{600 \mathrm{~nm}}$ measurements and the $\mathrm{pH}$ was monitored each hour.

\section{GTF activity assay}

GTF activity was determined in cell-free supernatants and in harvested cell fractions by measuring the release of reducing sugars using the DNS technique (Sumner and Howell 1935) in the presence of $10 \%(\mathrm{w} / \mathrm{v})$ sucrose in $100 \mathrm{mM}, \mathrm{pH} 5.4$ acetate buffer. Incubation was performed in an Eppendorf Thermomixer Comfort device (Eppendorf, Hamburg) at $30^{\circ} \mathrm{C}$. One activity unit (U) of total GTF activity is defined as the amount of enzyme producing $1 \mu \mathrm{mol}$ of glucose per minute from GTF activity under the assay reaction conditions (Morales-Arrieta et al. 2006). Protein concentration was determined by the Bradford method (Bradford 1976), using the Bio-Rad reagent and BSA (BioRad) as standards.

\section{In vitro EPS production}

EPS were produced from the supernatant and cellassociated enzyme fractions. For this purpose, the soluble GTF fraction was precipitated from the supernatant cultures by the addition of one volume of $50 \%(\mathrm{w} / \mathrm{v})$ polyethylene glycol 5000 and centrifugation $(7,000 \times g$, $5 \mathrm{~min}$ at $4^{\circ} \mathrm{C}$ ). The pellet of cells containing the cellassociated GTF fraction, was washed three times and resuspended in a minimal volume of $0.1 \mathrm{mM}, \mathrm{pH} 5.4$ acetate buffer (Quirasco et al. 1999). Polymer was produced in both fractions in the same buffer conditions containing $10 \%$ sucrose in final volume of $600 \mu \mathrm{L}$ and incubated at $30^{\circ} \mathrm{C}$ and $100 \mathrm{rpm}$ for $14 \mathrm{~h}$ (New Brunswick Scientific G24 shaker). The polymers produced from the cell-associated fraction were centrifuged as above to separate them from the cell whereas polymer produced from the supernatant fraction was precipitated by the addition of one volume of absolute ethanol and harvested by centrifugation $\left(2,367 \times g, 5 \mathrm{~min}\right.$ at $\left.4^{\circ} \mathrm{C}\right)$. Both polymers were resuspended in a minimum volume of distilled water and dialyzed against distilled water, eluted in a cellulose membrane (Mw cutoff of 12,400 Da SIGMAALDRICH), and dried in a LABCONO FreeZone 5.4 freeze-dryer.

\section{Hydrolysis of EPS}

Soluble and cell-associated ESPA and EPSB polymer fractions were subjected to enzyme hydrolysis with Fructozyme $\mathrm{L}^{\oplus}$ (kindly provided by Novozymes), a commercial enzymatic preparation obtained from Aspergillus niger combining endo- and exoinulinase activities toward $\beta-(2 \rightarrow 1)$ and endo- $\beta-(2 \rightarrow 6)$ D-Frup linkages, in $\mathrm{pH} 5,0.05 \mathrm{M}$, acetate buffer, at $60^{\circ} \mathrm{C}$; Dextranase (Enzimas y Productos Químicos S.A. de C.V., Mexico City), which hydrolyses $\alpha-(1 \rightarrow 6)$ D-Glc $p$ linkages, in $0.05 \mathrm{M}$ acetate buffer, $\mathrm{pH} 5$, at $50^{\circ} \mathrm{C}$; recombinant $E$. coli (levB) endolevanase from Bacillus licheniformis, which degrades endo- $\beta-(2 \rightarrow 6)$ D-Frup linkages (kindly provided by Dr. A. López-Munguía) in $\mathrm{pH}$ 6, $50 \mathrm{mM}$ potassium phosphate buffer at $37^{\circ} \mathrm{C}$; and endoinulinase Novozym ${ }^{\oplus} 960$ (Batch KNN00120 from Novozymes), which degrades endo- $\beta-(2 \rightarrow 6)$ D-Frup linkages, in $\mathrm{pH} 6$, $50 \mathrm{mM}$ potassium phosphate buffer at $60^{\circ} \mathrm{C}$. Acid hydrolysis was performed with $\mathrm{H}_{2} \mathrm{SO}_{4} 5 \%(\mathrm{v} / \mathrm{v})$ at $95^{\circ} \mathrm{C}, 1 \mathrm{hr}$.

Enzymatic and acid hydrolysis assays were performed in a volume of $0.5 \mathrm{~mL}$ containing $2 \% \mathrm{w} / \mathrm{v}$ of EPS and were incubated for $12 \mathrm{~h}$. Inulin from L. citreum, levan of B. subtilis (Ortiz-Soto et al. 2004) and dextran of L. mesenteroides B-512 PM 69,000 Da (Sigma) were used as controls. Hydrolyzed samples were analyzed by TLC using precoated TLC-sheets of Alugram ${ }^{\oplus}$ Xtra Sil G/UV254 with a mobile phase of 11:3:11:1 acetic acid:chloroform:ethanol: water mixture. The spots of products were detected by spraying with an alcoholic solution of $\alpha$-naphthol and sulfuric acid, followed by heating at $120^{\circ} \mathrm{C}$ for $3 \mathrm{~min}$.

\section{${ }^{1} \mathrm{H}$ - and ${ }^{13} \mathrm{C}$-NMR analysis of EPS}

The freeze-dried samples of each polymer were dissolved in $1.0 \mathrm{~mL}$ of $\mathrm{D}_{2} \mathrm{O}$ (Cambridge Isotope Laboratories, Inc.). 
NMR spectrum of soluble EPSA polymer was recorded on an Advance $700 \mathrm{MHz}$ spectrometer (Varian) operating at $700 \mathrm{MHz}$ for ${ }^{1} \mathrm{H}-\mathrm{NMR}$ and $175 \mathrm{MHz}$ for ${ }^{13} \mathrm{C}$-NMR. NMR spectra of both EPSB fractions were recorded on an Advance $400 \mathrm{MHz}$ spectrometer (Varian) operating at $400 \mathrm{MHz}$ for ${ }^{1} \mathrm{H}-\mathrm{NMR}$ and $100 \mathrm{MHz}$ for ${ }^{13} \mathrm{C}-\mathrm{NMR}$. All measurements were performed at room temperature and were obtained using a $1.0 \mathrm{~s}$ relaxation delay. The data were acquired and processed using VNMRJ 2.0 software. Chemical shifts are listed in parts per million (ppm) and were made on the basis of ${ }^{1} \mathrm{H}_{-}{ }^{1} \mathrm{H}$ COSY, ${ }^{1} \mathrm{H}_{-}{ }^{1} \mathrm{H}$ TOCSY, NOESY, DEPT, HSQC, and HMBC spectral analysis (Additional file 1).

\section{Additional file}

\section{Additional file 1: 2-D NMR analysis of EPSA and EPSB polymers.}

${ }^{1} \mathrm{H}-{ }^{1} \mathrm{H}$ COSY, ${ }^{1} \mathrm{H}-1 \mathrm{H}$ TOCSY, NOESY, HSQC, and HMBC spectral analysis of EPSA and EPSB-soluble fractions and DEPT, ${ }^{1} \mathrm{H}-{ }^{1} \mathrm{H}$ COSY, ${ }^{1} \mathrm{H}-{ }^{1} \mathrm{H}$ TOCSY, NOESY, HSQC, and HMBC spectral analysis of EPSB-soluble and cell-associated fractions.

\section{Abbreviations}

EPS: Extracellular polysaccharides; LAB: Lactic acid bacteria; NMR: Nuclear magnetic resonance; SEM: Scanning electron microscopy; GTF: Glycosyltransferase(s).

\section{Competing interests}

The authors declare that they have no competing interests.

\section{Authors' contributions}

ITR and MRA, characterized the growth profile of L. kimchii, preformed GTF activity assays, produced in vitro both EPSA and EPSB polymers, and performed structural characterization of EPS by enzymatic and acid hydrolysis. AMM, performed ${ }^{1} \mathrm{H}$ - and ${ }^{13} \mathrm{C}$-NMR structural characterization of both EPSA and EPSB polymers. MGG and RCM performed pulque fermentation, EPS-producing $L A B$ screening, purification and identification of studied LAB strains. MRA, MGG, ALM, FB, and AE conceived this study and designed experiments. MRA, AMM, ALM, FB, and AE wrote the paper. All the authors read and approved the final manuscript.

\section{Acknowledgements \\ This project was supported by PAPIIT-UNAM project IN207914. We thank to Mercedes Enzaldo (IBT-UNAM); Alejandro Camacho Cruz and Ma. Antonieta Silva (Facultad de Química, UNAM), for their technical support; Dr. Fernando García Hernández (IFC-UNAM), for biological sample preparation for SEM observation; Dr. Omar Novelo Peralta (IIM-UNAM) for SEM support of EPS samples; and M.C. Silvia Marquina Bahena (CIQ, UAEM) for RMN sample analysis support; Oscar Martínez for the critical review of this document.}

\section{Author details \\ 1Departamento de Ingeniería Celular y Biocatálisis, Instituto de Biotecnología, Universidad Nacional Autónoma de México (UNAM), Av. Universidad 2001. Col. Chamilpa, Cuernavaca Morelos 62210, México. ${ }^{2}$ Departamento de Biología, Facultad de Química, UNAM. Ciudad Universitaria, México D. F. Coyoacán 04510, México.}

Received: 10 July 2014 Accepted: 30 September 2014 Published: 7 October 2014

\section{References}

Ahmed RZ, Siddiqui K, Arman M, Ahmed N (2012) Characterization of high molecular weight dextran produced by Weissella cibaria CMGDEX3. Carbohydr Polym 90:441-446. doi:10.1016/j.carbpol.2012.05.063 Amari M, Arango LFG, Gabriel V, Robert H, Morel S, Moulis C, Gabriel B, Remaud-Siméon M, Fontagné-Faucher C (2012) Characterization of a novel dextransucrase from Weissella confusa isolated from sourdough. Appl Microbiol Biotechnol 97:5413-5422. doi:10.1007/s00253-012-4447-8

Bauer R, Bekker JP, van Wyk N, du Toit C, Dicks LMT, Kossmann J (2009) Exopolysaccharide production by lactose-hydrolyzing bacteria isolated from traditionally fermented milk. Int J Food Microbiol 131:260-264. doi:10.1016/j. ijfoodmicro.2009.02.020

Bounaix M-S, Gabriel V, Morel S, Robert H, Rabier P, Remaud-Siméon M, Gabriel B, Fontagné-Faucher C (2009) Biodiversity of exopolysaccharides produced from sucrose by sourdough lactic acid bacteria. J Agric Food Chem 57:10889-10897. doi:10.1021/jf902068t

Bounaix M-S, Gabriel V, Robert H, Morel S, Remaud-Siméon M, Gabriel B, Fontagné-Faucher C (2010) Characterization of glucan-producing Leuconostoc strains isolated from sourdough. Int J Food Microbiol 144:1-9. doi:10.1016/j. ijfoodmicro.2010.05.026

Bradford MM (1976) A rapid and sensitive method for the quantitation of microgram quantities of protein utilizing the principle of protein-dye binding. Anal Biochem 72:248-254

Chellapandian M, Larios C, Sanchez-Gonzalez M, Lopez-Munguia A (1998) Production and properties of a dextransucrase from Leuconostoc mesenteroides IBT-PQ isolated from "pulque", a traditional Aztec alcoholic beverage. J Ind Microbiol Biotechnol 21:51-56

Colson P, Jennings HJ, Smith IC (1974) Composition, sequence, and conformation of polymers and oligomers of glucose as revealed by carbon-13 nuclear magentic resonance. J Am Chem Soc 96:8081-8087

Dahech I, Fakhfakh J, Damak M, Belghith H, Mejdoub H, Belghith KS (2013) Structural determination and NMR characterization of a bacterial exopolysaccharide. Int J Biol Macromol 59:417-422. doi:10.1016/j. ijbiomac.2013.04.036

Ehrmann MA, Freiding S, Vogel RF (2009) Leuconostoc palmae sp. nov., a novel lactic acid bacterium isolated from palm wine. Int J Syst Evol Microbiol 59:943-947. doi:10.1099/ijs.0.005983-0

Eom H-J, Seo DM, Han NS (2007) Selection of psychrotrophic Leuconostoc spp. producing highly active dextransucrase from lactate fermented vegetables. Int J Food Microbiol 117:61-67. doi:10.1016/j.ijfoodmicro.2007.02.027

Escalante A, Rodríguez ME, Martínez A, López-Munguía A, Bolivar F, Gosset G (2004) Characterization of bacterial diversity in Pulque, a traditional Mexican alcoholic fermented beverage, as determined by 165 rDNA analysis. FEMS Microbiol Lett 235:273-279. doi:10.1016/j.femsle.2004.04.045

Escalante A, Giles-Gómez M, Hernandez G, Cordova Aguilar M, Lopez-Munguia A, Gosset G, Bolivar F (2008) Analysis of bacterial community during the fermentation of pulque, a traditional Mexican alcoholic beverage, using a polyphasic approach. Int J Food Microbiol 124:126-134. doi:10.1016/j. ijfoodmicro.2008.03.003

Escalante A, Giles-Gómez M, Esquivel Flores G, Matus Acuña V, Moreno-Terrazas R, López-Munguía A, Lappe-Oliveras P (2012) Pulque Fermentation. In: Hui YH (ed) Handb. Plant-Based Fermented Food Beverage Technol., Second Edition. CRC Press, Boca Raton, FL, pp 691-706

Giraffa G (2004) Studying the dynamics of microbial populations during food fermentation. FEMS Microbiol Rev 28:251-260. doi:10.1016/j.femsre.2003.10.005

Kim J, Chun J, Han H-U (2000) Leuconostoc kimchii sp. nov., a new species from kimchi. Int J Syst Evol Microbiol 50:1915-1919

Leemhuis H, Pijning T, Dobruchowska JM, van Leeuwen SS, Kralj S, Dijkstra BW, Dijkhuizen L (2013) Glucansucrases: Three-dimensional structures, reactions, mechanism, a-glucan analysis and their implications in biotechnology and food applications. J Biotechnol 163:250-272. doi:10.1016/j.jbiotec.2012.06.037

Maina NH, Tenkanen M, Maaheimo H, Juvonen R, Virkki L (2008) NMR spectroscopic analysis of exopolysaccharides produced by Leuconostoc citreum and Weissella confusa. Carbohydr Res 343:1446-1455. doi:10.1016/j. carres.2008.04.012

Minervini F, De Angelis M, Surico RF, Di Cagno R, Gänzle M, Gobbetti M (2010) Highly efficient synthesis of exopolysaccharides by Lactobacillus curvatus DPPMA10 during growth in hydrolyzed wheat flour agar. Int J Food Microbiol 141:130-135. doi:10.1016/j.ijfoodmicro.2010.03.014

Morales-Arrieta S, Rodríguez ME, Segovia L, López-Munguía A, Olvera-Carranza C (2006) Identification and functional characterization of levS, a gene encoding for a levansucrase from Leuconostoc mesenteroides NRRL B-512 F. Gene 376:59-67. doi:10.1016/j.gene.2006.02.007

Newbrun E, Baker S (1968) Physico-chemical characteristics of the levan produced by Streptococcus salivarius. Carbohydr Res 6:165-170. doi:10.1016/S0008-6215 (00)81506-2 
Oh H-M, Cho Y-J, Kim BK, Roe J-H, Kang S-O, Nahm BH, Jeong G, Han H-U, Chun J (2010) Complete genome sequence analysis of Leuconostoc kimchii IMSNU 11154. J Bacteriol 192:3844-3845. doi:10.1128/JB.00508-10

Olivares-Illana V, Wacher-Rodarte C, Le Borgne S, López-Munguía A (2002) Characterization of a cell-associated inulosucrase from a novel source: A Leuconostoc citreum strain isolated from Pozol, a fermented corn beverage of Mayan origin. J Ind Microbiol Biotechnol 28:112-117

Ortiz-Soto ME, Olivares-Illana V, López-Munquía A (2004) Biochemical properties of inulosucrase from Leuconostoc citreum CW28 used for inulin synthesis. Biocatal Biotransformation 22:275-281. doi:10.1080/10242420400014251

Palomba S, Cavella S, Torrieri E, Piccolo A, Mazzei P, Blaiotta G, Ventorino V, Pepe O (2012) Polyphasic screening, homopolysaccharide composition, and viscoelastic behavior of wheat sourdough from a Leuconostoc lactis and Lactobacillus curvatus exopolysaccharide-producing starter culture. Appl Environ Microbiol 78:2737-2747. doi:10.1128/AEM.07302-11

Park J-H, Ahn H-J, Kim S, Chung C-H (2013) Dextran-like exopolysaccharideproducing Leuconostoc and Weissella from kimchi and its ingredients. Food Sci Biotechnol 22:1047-1053. doi:10.1007/s10068-013-0182-x

Patel S, Majumder A, Goyal A (2011) Potentials of exopolysaccharides from lactic acid bacteria. Indian J Microbiol 52:3-12. doi:10.1007/s12088-011-0148-8

Quirasco M, Lopez-Munguia A, Remaud-Simeon M, Monsan P, Farres A (1999) Induction and transcription studies of the dextransucrase gene in Leuconostoc mesenteroides NRRL B-512 F. Appl Environ Microbiol 65:5504-5509

Sanchez-Marroquin A, Hope PH (1953) Agave juice, fermentation and chemical composition studies of some species. J Agric Food Chem 1:246-249

Seymour FR, Knapp RD, Bishop SH (1976) Determination of the structure of dextran by ${ }^{13} \mathrm{C}$-nuclear magnetic resonance spectroscopy. Carbohydr Res 51:179-194. doi:10.1016/S0008-6215(00)83325-X

Seymour FR, Knapp RD, Jeanes A (1979) Structural analysis of levans by use of ${ }^{13}$ C-n.m.r. spectroscopy. Carbohydr Res 72:222-228. doi:10.1016/S0008-6215 (00)83940-3

Shimamura A, Tsuboi K, Nagase T, Ito M, Tsumori H, Mukasa H (1987) Structural determination of D-fructans from Streptococcus mutans, serotype b, C, e, and f strains, by ${ }^{13} \mathrm{C}-$-n.m.r. spectroscopy. Carbohydr Res 165:150-154

Shukla R, Shukla S, Bivolarski V, Iliev I, Ivanova I, Goyal A (2011) Structural characterization of insoluble dextran produced by Leuconostoc mesenteroides NRRL B-1149 in the presence of maltose. Food Technol Biotechnol 49:291-296

Sumner JB, Howell SF (1935) A method for determination of saccharase activity. J Biol Chem 108:51-54

Tamura K, Stecher G, Peterson D, Filipski A, Kumar S (2013) MEGA6: Molecular evolutionary genetics analysis version 6.0. Mol Biol Evol 30:2725-2729. doi:10.1093/molbev/mst197

Tieking M, Kaditzky S, Valcheva R, Korakli M, Vogel RF, Ganzle MG (2005) Extracellular homopolysaccharides and oligosaccharides from intestinal lactobacilli. J Appl Microbiol 99:692-702. doi:10.1111/j.1365-2672.2005.02638.x

Tomašić J, Jennings HJ, Glaudemans CPJ (1978) Evidence for a single type of linkage in a fructofuranan from Lolium perenne. Carbohydr Res 62:127-133. doi:10.1016/S0008-6215(00)83384-4

Uzochukwu S, Balogh E, Loefler RT, Ngoddy PO (2001) Structural analysis by ${ }^{13}$ C-nuclear magnetic resonance spectroscopy of glucans elaborated by gum-producing bacteria isolated from palm wine. Food Chem 73:225-233

Uzochukwu S, Balogh E, Loefler RT, Ngoddy PO (2002) Structural analysis by ${ }^{13} \mathrm{C}$-nuclear magnetic resonance spectroscopy of glucan extracted from natural palm wine. Food Chem 76:287-291

Van der Meulen R, Grosu-Tudor S, Mozzi F, Vaningelgem F, Zamfir M, Font de Valdez G, De Vuyst $L$ (2007) Screening of lactic acid bacteria isolates from dairy and cereal products for exopolysaccharide production and genes involved. Int J Food Microbiol 118:250-258. doi:10.1016/j.ijfoodmicro.2007.07.014

Van Hijum SAFT, Kralj S, Ozimek LK, Dijkhuizen L, van Geel-Schutten IGH (2006) Structure-function relationships of glucansucrase and fructansucrase enzymes from lactic acid bacteria. Microbiol Mol Biol Rev 70:157-176. doi:10.1128/ MMBR.70.1.157-176.2006

Vasileva T, Iliev I, Amari M, Bivolarski V, Bounaix M-S, Robert H, Morel S, Rabier P, Ivanova I, Gabriel B, Fontagné-Faucher C, Gabriel V (2012) Characterization of glycosyltransferase activity of wild-type Leuconostoc mesenteroides strains from bulgarian fermented vegetables. Appl Biochem Biotechnol 168:718-730. doi:10.1007/s12010-012-9812-7

Vu B, Chen M, Crawford RJ, Ivanova EP (2009) Bacterial extracellular polysaccharides involved in biofilm formation. Molecules 14:2535-2554. doi:10.3390/molecules14072535

Weisburg WG, Barns SM, Pelletier DA, Lane DJ (1991) 16 S ribosomal DNA amplification for phylogenetic study. J Bacteriol 173:697-703

doi:10.1186/2193-1801-3-583

Cite this article as: Torres-Rodríguez et al:: Screening and

characterization of extracellular polysaccharides produced by

Leuconostoc kimchii isolated from traditional fermented pulque

beverage. SpringerPlus 2014 3:583.

\section{Submit your manuscript to a SpringerOpen ${ }^{\odot}$ journal and benefit from:}

- Convenient online submission

- Rigorous peer review

- Immediate publication on acceptance

- Open access: articles freely available online

- High visibility within the field

- Retaining the copyright to your article

Submit your next manuscript at $>$ springeropen.com 